\title{
THEORETICAL FOUNDATION AND LITERATURE REVIEW OF THE STUDY OF CONCEPT MAPS USING EYE TRACKING METHODOLOGY
}

\author{
Bases teóricas y revisión bibliográfica del estudio \\ de los mapas conceptuales con el \\ seguimiento de la mirada
}

\section{Cristòfol Rovira}

Nota: Este artículo puede leerse traducido al español en:

http://www.elprofesionaldelainformacion.com/contenidos/2016/ene/07_esp.pdf

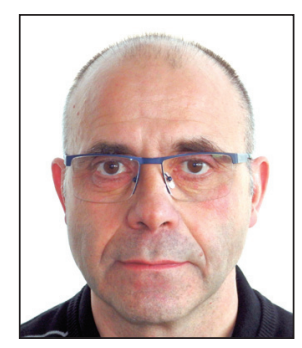

Cristòfol Rovira is professor at the Communication Department of the Pompeu Fabra University (UPF). He teaches in journalism and advertising programs, in the Master's Degree in Social Communication (UPF), the Master in Digital Documentation (UPF), the Master in Search Engines (UPF) and Master in Management Digital Content (UB - UPF). His research focuses on search engine optimization, usability, search engine marketing, and on concept maps using eye tracking methodology. He is the academic secretary of the Faculty of Communication at the University Pompeu Fabra, and co-director of the Hipertext.net journal. http://orcid.org/0000-0002-6463-3216

Universitat Pompeu Fabra, Departament de Comunicació, Grup de Recerca de Periodisme Roc Boronat, 138. 08018 Barcelona, España cristofol.rovira@upf.edu

\begin{abstract}
In this paper, we will be carrying out an in-depth analysis of a series of investigations involving concept maps used in eye tracking methodology. First, the background to this kind of research is analyzed: on the one hand we will focus on generic scientific literature about those concept maps with theoretical foundations in the psychology of learning, and second the literature of eye tracking in teaching and learning will be reviewed. Finally, we will center our attention on the way in which the literature for these two areas overlaps. A total of 15 published works on concept maps using eye tracking were located and subsequently the quality of these papers, their visibility, topics, and results were analyzed. The findings show there are very few published works on this subject, all originated from dispersed sources which proved difficult to locate, despite the fact that eye tracking methodology lends itself perfectly to the study of concept maps. We predict that in coming years there will be many more publications in this field.
\end{abstract}

\section{Keywords}

Concept maps; Knowledge maps; Graphic organizer; Node-link maps; Eye tracking; Eye movements; Comprehensive analysis; Bibliography; Literature reviews.

\section{Resumen}

En este artículo se presentan los resultados de una revisión bibliográfica sobre las investigaciones publicadas hasta la fecha sobre mapas conceptuales aplicando la metodología del seguimiento de la mirada. Se estudian los antecedentes de este tipo de trabajos: por un lado la producción científica genérica sobre mapas conceptuales con bases teóricas en la psicología del aprendizaje y por otro lado la metodología del seguimiento de la mirada aplicada a la investigación sobre la enseñanza y el aprendizaje. Finalmente se concreta en la intersección de ambos tipos de trabajos y se reseñan 15 publicaciones sobre mapas conceptuales usando el seguimiento de la mirada. Se analiza la calidad de estos trabajos, su visibilidad, los temas tratados y los resultados obtenidos. Los conclusiones son que hay pocas publicaciones, dispersas y con poca visibilidad y que el seguimiento de la mirada se aplica de forma poco eficiente. A pesar de estas conclusiones, se constata que la metodología del seguimiento de la mirada se adecua muy bien al estudio de los mapas conceptuales y se pronostica que en los próximos años habrán muchos más trabajos en este campo. 


\section{Palabras clave}

Mapas conceptuales; Mapas de conocimiento; Organizador gráfico; Mapas de nodos y enlaces; Seguimiento de la mirada; Eye tracking; Estado de la cuestión; Bibliografía; Revisión bibliográfica.

Rovira, Cristòfol (2016). "Theoretical foundation and literature review of the study of concept maps using eye tracking methodology". El profesional de la información, v. 25, n. 1, pp. 59-73.

http://dx.doi.org/10.3145/epi.2016.ene.07

\section{Introduction}

Concept maps are a kind of graphic representation which show how different concepts relate to each other. They are made up of nodes (concept squares) and links (lines with tags) which are designed to represent knowledge and are used in a wide range of activities to make learning easier. There are different modes of concept maps that come together under different names, each with their own specific characteristics, some of which may even contain different lines of investigation. Most of them, however, are based on theoretical work in the field of psychology in research carried out by David P. Ausubel and presented in the theory of meaningful learning (Ausubel, 1968). Investigation into the use of concept maps goes as far back as the end of the nineties and the number of related works published has increased gradually year by year (Nesbit; Adesope, 2006). These works encompass many different subject matters, research methods and even the theories which can give meaning to these works, but most of them are based on psychology in learning, as concept maps are most commonly used as a learning tool.

The actual methodology of eye tracking itself has been widely used in learning research (Lai et al., 2013), notably in reading comprehension and problem-solving, as well as for more general use in studying teaching and learning strategies. Research on concept maps falls into the latter category.

Although it is a relatively recent field of study, it has great potential utility given that eye tracking methodology is perfectly applicable when studying concept maps (Rovira, 2013). This methodology has already proven highly effective in graph reading (Mayer, 2010) and research into reading, (Rayner; Chace; Slattery; Ashby, 2006) because concept maps are basically graphs which we read.

The main hindrance encountered in this research was the sheer lack of previous research and the difficulty involved in tracing any related material. The main difficulty lies in the wide range of terms used to describe concept maps in scientific bibliography and the limited knowledge researchers themselves possess because of the meagre amount of previously published material.

This article aims to seek a solution to the aforementioned lack of data by carrying out an exhaustive bibliographic study on all the previously published material about concept maps using eye tracking up to date. In all, only 15 works were found: one PhD dissertation, five congress presentations, one technical document, and seven articles. All the documents, with the exception of three, were indexed in
Google Scholar. All the indexed articles were found in Scopus and the remaining six were located in Web of Science $(S S C l)$. The first work was published in 2007 and the most recent in 2014. The works are somewhat scattered as they make little reference to each other and are not easily findable. If we exclude the article by Amadieu (2009), none of the other publications are readily cited. In fact, in a great number of the sources researched, the methodology of eye tracking was dealt with in a rather insufficient way, failing to exploit the potential of this method.

\section{A concept map is a graphic diagram made up of concepts and relationships between concepts}

\section{Methodology}

The main objectives of this article are the following: To present an overview of the range of concept maps of any relevance in specialized bibliographies; analyze the theoretical groundwork which establishes how to create and use these maps; examine the main themes; identify the most productive lines of investigation; and finally to examine in greater depth those works in which eye tracking methodology has been applied in studies regarding concept maps. In order to achieve the aforementioned objectives, an exhaustive bibliographical analysis was carried out of a descriptive and evaluative nature. First of all, the articles are described, including their main theme, quality, and findability. Then, the way in which the methodology of eye tracking was applied is assessed. And, finally, conclusions are drawn with an eye towards the future within this field of research. In order to locate the 15 articles, the following databases and search engines were employed: Google Scholar, Web of Science, Scopus, and ERIC. The search equations were as follows:

For the concept of a concept map:

"concept mapping" OR "concept map" OR "graphic organizer" OR "node link diagram" OR "node and link diagram" OR "knowledge map" OR "knowledge mapping" OR "semantic map" OR "semantic mapping" OR "mind map" OR "mind mapping" OR "concept diagram"

For the concept of eye tracking:

"eye tracker" OR "eye-tracker" OR eyetracker OR "eye tracking" OR "eye-tracking" OR eyetracking OR "eye movement" OR "eye movements"

To complete the study, both groups of terms were joined up using the AND operator and searches were restricted to 


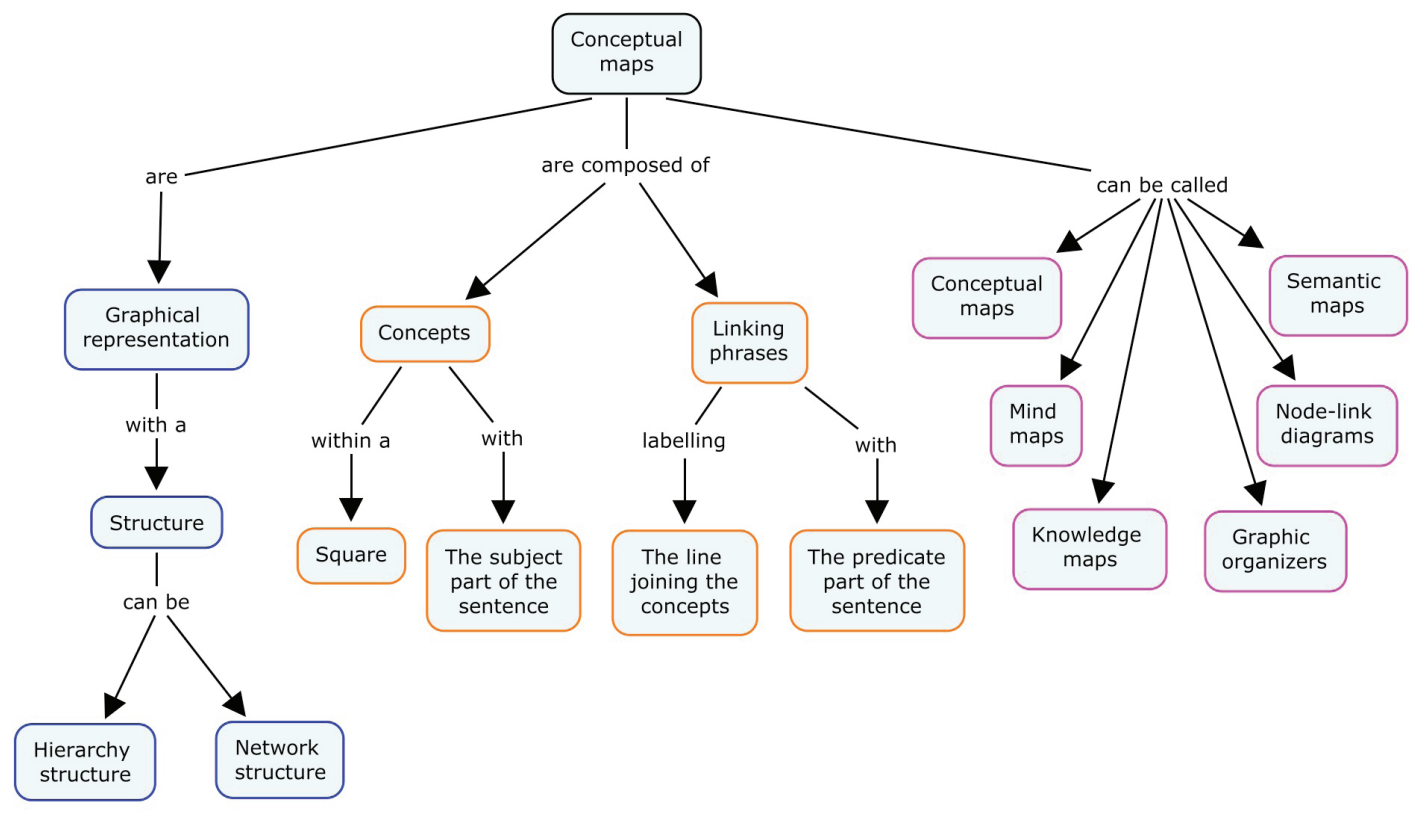

Figure 1. Definition of a concept map

titles or key words. From the results obtained, a selection was made of those works which best encompass the lines of investigation into the most productive and consolidated concept maps currently available, all of which are related to teaching and learning processes.

\section{Origins and definitions of concept maps}

Concept maps are a kind of graphic framework which allow to depict knowledge (Novak; Cañas, 2006; Novak; Gowin, 1984; Novak, 1990a, 1990b). They are made up of concepts and relationships between different concepts, generally referred to as cross links. The concepts are usually shown inside a square and the cross link phrases label the lines or arrows which join up two or more concepts. See figure 1 . The concepts are the subject matter of the phrases (nouns or adjectives) and the cross links tend to contain verbs and prepositions. The origin of concept maps can be traced through the theories of David P. Ausubel in his work on meaningful learning (Ausubel, 1963, 1968, 2012) which gave rise to a number of graphic tools aimed at facilitating learning. There are three basic elements in Novak's definition which are present in other types of maps: graphs or frameworks, concepts or ideas, and relationships or links between these concepts.

The first reference to concept maps in a specialized bibliography (Åhlberg, 2004) was at the end of the seventies (Stewart, 1979), but it was not until the nineties that the amount of research using concept mapping increased notably (Nesbit; Adesope, 2006). Different kinds of maps were devised and developed individually, complying with the three basic characteristics previously stated. Some of the authors and titles, which can be found in the bibliography, are as follows:

Some authors (Åhlberg, 2004; Davies, 2011; Eppler, 2006; Milam; Santo; Heaton, 2000) have analyzed the names that can be found in the bibliography; are as follows:

- Concept maps (Novak, 1990a).

- Mind maps (Buzan; Buzan, 1995).

- Knowledge maps (O'Donnell; Dansereau; Hall, 2002; Wiegmann; Dansereau; McCagg; Rewey; Pitre, 1992).

- Spider maps.

- Semantic maps (Lambiotte; Dansereau; Cross; Reynolds, 1989).

- Semantic networks.

- Graphic organizers (Estes; Mills; Barron, 1969; Moore; Readence, 1984).

- Node-link diagrams (Dansereau, 2005; McCagg; Dansereau, 1991).

- Conceptual diagrams.

- Etc.

Some authors (Nesbit; Adesope, 2006, 2013) cite the works of Quillian at the end of the sixties as one of the earliest sources of theoretical information for modern-day maps owing to their theories regarding semantic maps (Collins; Quillian, 1969; Quillian, 1967). These works should, however, be contextualized in a different field than the subject matter dealt with in this article. It involves the use of maps to represent the human memory with a view towards developing software in order to imitate its functioning pattern. This is a tactic which has been employed in such areas as Computer Linguistics, Artificial Intelligence, or Robotics.

Investigation has also been made into node-link graphs overlapping from other fields such as usability and visualization of information (Ghoniem; Fekete; Castagliola, 2004; Ghoniem, 2005; Henry; Fekete; McGuffin, 2007; Holten; Van-Wijk, 2009), linguistics (Haspelmath, 2003; Van-Der-Auwera; Plungian, 1998; Van Der Auwera, 2008), and library and information sciences (Tramullas; Sánchez-Casabón; Garrido-Picazo, 2009). These works are not, however, cited in bibliography with theoretical grounding in psychology. 
All the different varieties of maps we have mentioned contain a structure consisting of nodes and links, and can be differentiated using three basic criteria: they either associate (or not, as the case may be) the text to the related phrases, the position of the original concept (center or top), and the grid pattern for general organization in maps (network, star, or hierarchy). Some of these works have been established as lines of investigation, especially in concept maps by Novak (1990a), knowledge maps by Dansereau (McCagg; Dansereau, 1991) and graphic organizers (Estes et al., 1969).

As far as the main objective of this article is concerned, all of the mentioned works may be considered valid ways to use maps, but the main aim here is to examine the research which has applied the methodology of eye tracking to graphs using the "node-link" paradigm.

There is a fair amount of confusion about the terminology used in scientific literature. A number of authors use the generic term "graphic organizers", and within this term they include concept maps by Novak and knowledge maps by Dansereau (Stull; Mayer, 2007; Vekiri, 2002); however other authors use "knowledge maps" as a generic term (McCagg; Dansereau, 1991; Wiegmann et al., 1992), and still there are others who consider the term "concept maps" to be the most comprehensive term (Milam et al., 2000; Nesbit; Adesope, 2006, 2013). In this article, we have decided to use the latter and when we make any specific reference to Novak's maps, we will use the expression "Novakian concept maps".

\section{Theoretical groundwork in concept maps}

The most common theories involved in creating, using, and studying concept maps belong to the field of cognitive psychology (Ausubel; Vygotski; Piaget; Bruner). Nevertheless, some versions of graphs consisting of nodes and links have been studied in other fields such as Linguistics (Van-DerAuwera, 2008), Information visualization, and Human computer interaction (Ghoniem et al., 2004; Henry et al., 2007).

Concept maps are versatile and flexible tools which have been applied for varying purposes such as strengthening learning techniques, assessing students, assisting creativity in writing (brainstorming), reading comprehension, exchanging ideas in work groups, and communicating ideas (presentations). It is, however, in the processes of teaching and learning where we encounter the vast majority of literature in this field. The first research was carried out at the end of the eighties and the beginning of the nineties (Daley;
Shaw; Balistrieri; Glasenapp; Piacentine, 1999; Markham; Mintzes; Jones, 1994; Roth; Roychoudhury, 1992, 1993; J. D. Wallace; Mintzes, 1990; Willerman; Mac-Harg, 1991) and the number of works published has gradually increased every year up to the present. (Adesope; Nesbit, 2009; Nesbit; Adesope, 2006, 2013; O'Donnell et al., 2002; Vekiri, 2002).

\section{Concept maps can also be referred to as knowledge maps, mind maps, semantic maps, graphic organizers, conceptual diagrams, node-link graphs...}

More specifically, in the study and use of concept maps for learning, we will consider three main lines of work, all of which can be traced back explicitly to the theory of meaningful learning created by Ausubel (1963). Each line of work uses one kind of map which is given a name and has specific characteristics. The investigation will generally focus on specific aspects of the learning process. See table 1.

The theory of meaningful learning by Ausubel (1963, 1968, 2012) established theoretical grounding and led the way in these three lines of inquiry and for most of the subsequent scientific production of concept maps when they are applied to the field of teaching and learning. The central idea of Ausubel's theory is that the learning process will be produced in a more efficient or significant, not memorytesting way, if newly-acquired knowledge can be related in great part to what the student already knows. Therefore, in order to achieve success in the learning process, the students would need to have assimilated this knowledge previously. This is known as "advance organizers", and comes in the form of general and abstract ideas which depict a general overview, as well as being relevant for recently assimilated knowledge (Ausubel, 1960, 1978). Advance organizers allow to build a platform or scaffolding (Mayer, 1979) for new learning that students will be able to use precisely in order to organize their knowledge and to distinguish between what is important, to be able to draw significant conclusions between newly-acquired information and their previously-attained knowledge.

Concept maps are derived directly from the idea of "advance organizers" which were originally developed by means of fragments of text. They later evolved to include graphs and

Table 1. Main research lines related to concept maps

\begin{tabular}{|l|l|l|l|}
\hline \multicolumn{1}{|c|}{ Name of map } & \multicolumn{1}{|c|}{ Main author/s } & \multicolumn{1}{c|}{ Key issue of the research } & \multicolumn{1}{c|}{ Specific characteristics of the maps } \\
\hline Graph organizers & Estes et al., 1969 & $\begin{array}{l}\text { Maps used to facilitate reading } \\
\text { comprehension }\end{array}$ & - The links are not usually labelled \\
\hline Concept map & Novak, 1990a & Learning by creating maps & $\begin{array}{l}\text { - Hierarchic structure } \\
\text { - The most general and abstract concepts are at the top } \\
\text { - The links always have labels }\end{array}$ \\
\hline Knowledge map & McCagg; Dansereau, 1991 & Learning by map reading & $\begin{array}{l}\text { - Standardized links } \\
\text { - Standardized structures } \\
\text { - Design based on the Gestalt principles } \\
\text { - Link lines with direction symbols }\end{array}$ \\
\hline
\end{tabular}


were called "graphic organizers". Concept maps are an ideal tool when playing the role of graphic organizers in order to depict concepts in an easy way and give a general and abstract vision about a specific subject by means of a concept network. They allow us to apply the idea of advance organizers in which students are able to identify concepts they already understand alongside new ones, all contained in just one general context dealing with all the most important items of knowledge about the theme in question.

In addition to concept maps, other kinds of graphs have been used to play the part of graphic organizers such as matrices, lists, flow charts, timelines, and tables. In all these cases they aim, with the use of graphic representation, to depict the relationship between concepts by their position, linking lines or intersections of figures. There is also a certain amount of confusion regarding the term "graphic organizer" and authors have been unable to agree in establishing a definitive terminology (Merkley; Jefferies, 2000; Moore; Readence, 1984). This is not the only point of contention - many investigations assume the term "graphic organizers' refers to node-link graphs (that is to say concept maps) while we may really be working with matrices.

Novakian concept maps and Dansereau's knowledge maps, either because of their temporary nature or their internal traits, may be considered two distinct kinds of graph organizers with individually defined characteristics which consolidated the earlier, rather vague, beginnings in graph organizers (Nesbit; Adesope, 2006; Robinson; Katayama; Dubois; Devaney, 1998). In fact, we could establish a two-tier level of consolidation. On the first stage, we could situate Novak's concept maps, where two basic conditions of graph organizers are applied. The first condition is that they must have a hierarchy, while the second is that the relationships between the concepts must always come with labels containing a linking phrase made up of the verbal composition of the phrases. Knowledge maps would be on a second level as the links and structure must also be standardized in compliance with previous models.

Concept maps are applied to learning methods based on the significant learning theories of David P. Ausubel, according to whom the learning process will be more significant rather than memory based if new knowledge input can be related largely to that which the student has already retained

In research dealing with concept maps, other theories, models, or hypotheses grounded in psychology are often cited, thus allowing us to establish the pattern of research, debate the proposed objectives, and later contextualize and explain the results obtained (Nesbit; Adesope, 2006, 2013; Vekiri, 2002). The leading works in this field are: Dual coding (Paivio, 1986, 1991), Cognitive load theory (Sweller, 1988), Conjoint retention theory (Kulhavy; Lee; Caterino, 1985), Activity theory (Leontyev, 1972), Visual argument theory (Waller, 1981), and Assimilation theory (Mayer, 1979). See table 2.

\section{Research into concept maps}

Concept maps have been used for more than 20 years in primary and secondary schooling as well as in universities in subjects such as Social Sciences, Humanities, Science,

Table 2. Principal psychological theories related to investigation into concept maps

\begin{tabular}{|c|c|c|c|c|}
\hline $\begin{array}{l}\text { Name of the theory } \\
\text { teoria/hypothesis }\end{array}$ & $\begin{array}{l}\text { Main } \\
\text { author/s }\end{array}$ & Year & Main argument & $\begin{array}{l}\text { Degree of application } \\
\text { in concept maps }\end{array}$ \\
\hline Significant learning & Ausubel & 1968 & $\begin{array}{l}\text { The learning process is produced in a significant and not a memory- } \\
\text { oriented mode if new knowledge can be substantially related to what } \\
\text { the student has already learned. }\end{array}$ & High \\
\hline Dual coding & Paivio & 1986 & $\begin{array}{l}\text { The graphs and texts are represented in two ways in our memory: } \\
\text { visually and verbally. The two representations are related, and when } \\
\text { combined will benefit our memory retention and assist in learning. }\end{array}$ & High \\
\hline Cognitive load theory & Sweller & 1988 & $\begin{array}{l}\text { Cognitive load refers to the mental effort required in memory control. } \\
\text { Cognitive load theory identifies three types of load: cognitive intrinsic, } \\
\text { strange and pertinent. The resulting analysis of the different kinds of } \\
\text { cognitive load, allows us to establish guidelines to enable us to pre- } \\
\text { sent information in the right conditions so as to guarantee optimum } \\
\text { intellectual performance. }\end{array}$ & High \\
\hline $\begin{array}{l}\text { Conjoint retention } \\
\text { theory }\end{array}$ & Kulhavy & 1985 & $\begin{array}{l}\text { It is an extension of Dual coding which explains how we acquire infor- } \\
\text { mation using graphs, geographic maps in particular, bearing in mind } \\
\text { the symbols, icons and reference points they tend to include. }\end{array}$ & Low \\
\hline Activity theory & Leontyev & 1972 & $\begin{array}{l}\text { The Activity theory is a metatheory or an umbrella term applied to } \\
\text { a number of fields. In teaching, this theory postulates that students } \\
\text { learn more deeply by practising and carrying out activities rather than } \\
\text { passive behaviour such as listening, reading or looking up informa- } \\
\text { tion. }\end{array}$ & Low \\
\hline Visual argument theory & Waller & 1981 & $\begin{array}{l}\text { Graphic representations are effective because their processing requi- } \\
\text { res less cognitive transformation than reading texts and therefore do } \\
\text { not overload the limits of our work memory. }\end{array}$ & Low \\
\hline Assimilation theory & Mayer & 1979 & $\begin{array}{l}\text { Graphs allow us to build a mental representation of a text and set the } \\
\text { scene before reading. }\end{array}$ & Low \\
\hline
\end{tabular}


and Technology (Nesbit; Adesope, 2013). They have, by and large, been used for transmitting and learning knowledge, whether it be verbal or conceptual. A whole host of computer programs have also been developed to enable to create and edit these maps (Rovira, 2005), many of which were devised for an educational environment. In spite of this extensive collective experience, there are still many question marks as to why they work, and how to effectively utilize them.

The amount of research into concept maps used in training and learning has gradually increased since the end of 1980 (Nesbit; Adesope, 2006). A number of authors have examined these works and identified the most common themes of investigation, the theories involved, the targets aimed at, the methodology applied, and the results obtained (Cañas et al., 2003; Lambiotte et al., 1989; Milam et al., 2000; Moore; Readence, 1984; Nesbit; Adesope, 2006, 2013; Vekiri, 2002; Winn, 1991).

\section{Eye tracking methodology provides us} with notions as to how each individual processes information. Some authors consider it to be a "window to our mind"

Most of these studies assess the effectiveness of concept maps in processes of teaching/learning, whether it be as a tool to transmit knowledge (concept map reading), as a means of carrying out learning tasks (creating concept maps), or as an assessment tool for work already completed (assessment tests with concept maps), see table 3. Other studies attempt to identify the optimum characteristics of concept maps in order to meet their targets (map desig- ning), or to appreciate whether individual differences (such as experts versus novices) are a conditioning factor in the learning process. The latest trends point towards the development of computer programs to create concept maps which give ideas to those authors who wish to present maps in a more interactive and dynamic fashion (Nesbit; Adesope, 2005; Rueda, Larranaga; Arruarte; Elorriaga, 2003).

\section{Concept maps and eye tracking}

Eye tracking is a research methodology used in a wide array of fields including publicity, psychology, usability, and human-computer interaction (Marcos; González-Caro, 2010). It involves identifying and analyzing zones on a computer screen, gazing at the theme in question, and carrying out tasks which are being investigated. It is based on the mindgazing (Just; Carpenter, 1980) hypothesis, according to which eye movements enable us to trace with great accuracy where the viewer is directing his/her attention, thus presenting us with indications as to the motivation and cognitive processing of individuals. While it is fair to say there are some studies on this matter that might consider the results inconsistent, it is a widely accepted hypothesis (Duchowski, 2003; Rayner et al., 2006; Rayner, 1998), especially when carrying out complex tasks which involve processing large amounts of information, such as learning, visualizing multimedia material, and reading (Frenck-Mestre; Pynte, 1997; She; Chen, 2009). The evidence that eye tracking gives us insight into how people process information has led some authors to classify it as a "mind window" (Grant; Spivey, 2003).

Researchers tend to use two kinds of eye movements to establish metric guidelines allowing them to draw conclusions about the behavior and way of processing information. The two are saccadic movements and staring. The saccadic mo-

Table 3. Main themes of investigation into concept maps

\begin{tabular}{|c|c|}
\hline Theme & Main author/s \\
\hline Learning by creating maps & $\begin{array}{l}\text { Amadieu et al., 2009; Chang; Sung; Chen, 2001; Hay, 2007; Horton et al., 1993; } \\
\text { Lambiotte; Dansereau, 1992; Novak; Cañas, } 2006\end{array}$ \\
\hline $\begin{array}{l}\text { Learning by consulting and studying previously created } \\
\text { maps }\end{array}$ & $\begin{array}{l}\text { Nesbit; Adesope, 2011; O'Donnell et al., 2002; D. F. Wallace, 1998; Willerman; Mac- } \\
\text { Harg, } 1991\end{array}$ \\
\hline Comparison between creating and reading a map & $\begin{array}{l}\text { Karpicke; Blunt, 2011; Lim; Lee; Grabowski, 2009; O’Donnell et al., 2002; Stull; } \\
\text { Mayer, } 2007\end{array}$ \\
\hline Comparing concept map learning with other tools & $\begin{array}{l}\text { Chang et al., 2001; Dansereau; Moreland; Chmielewski, 1997; Hall; O’Donnell, } \\
1996\end{array}$ \\
\hline Reading comprehension texts with the aid of concept maps & DiCecco; Gleason, 2008; Jiang; Grabe, 2007; Robinson; Kiewra, 1995 \\
\hline Designing effective concept maps & D. F. Wallace, 1998; Wiegmann et al., 1992 \\
\hline $\begin{array}{l}\text { Comparing the effectiveness of concept maps by taking } \\
\text { individual differences into account }\end{array}$ & Amadieu et al., 2009; Lambiotte et al., 1989; O'Donnell et al., 2002 \\
\hline Learning assessment using concept maps & $\begin{array}{l}\text { Markham et al., 1994; J. D. Wallace; Mintzes, 1990; Kinchin; Hay; Adams, 2000; No- } \\
\text { vak; Gowin, 1984; Pearsall; Skipper; Mintzes, 1997; Ruiz-Primo; Shavelson, 1996; } \\
\text { Turns; Atman; Adams, } 2000\end{array}$ \\
\hline Learning in a collaborative way using concept maps & $\begin{array}{l}\text { Esiobu; Soyibo, 1995; Haugwitz; Nesbit; Sandmann, 2010; Okebukola; Olugbe- } \\
\text { miro, 1988; Patterson; Dansereau; Wiegmann, 1993; Roth; Roychoudhury, 1993; } \\
\text { Stoyanova; Kommers, 2002; Van-Boxtel; Van-der-Linden; Roelofs; Erkens, } 2002\end{array}$ \\
\hline $\begin{array}{l}\text { Concept maps used to plan and develop a curriculum } \\
\text { design map }\end{array}$ & Cristea; Okamoto, 2001; Edmondson, 2000; Novak, 1998 \\
\hline Concept maps used to empower creativity in writing & Anderson-Inman; Horney, 1996; Sturm; Rankin-Erickson, 2002 \\
\hline
\end{tabular}


vements are those which act in a straight line and occur between one stare and another. It is only when we focus on something for a few milliseconds that we are able to obtain information which will later be processed to perceive an overall view of a word, an image, or any other element we may be looking at. By using the analysis obtained about the number and duration of fixations, or the direction of the saccadic movement, we are able to ascertain with a certain degree of effectiveness where the attention of the person is focused, and even the kind of cognitive processing used. For example, it is generally agreed that an increase in the number of fixations, or the amount of time spent gazing, denotes that the person is facing a complex task (Ball; Lucas; Miles; Gale, 2003; Epelboim; Suppes, 2001; Hegarty; Just, 1993; Holmqvist et al., 2011; Rayner et al., 2006; Rayner, 1998; Underwood; Jebbett; Roberts, 2004)

Eye tracking has been widely and successfully applied in the field of learning research in recent decades. Lai (2013) identified up to 113 investigations published in the journal Web of Science between 2000 and 2013 where eye tracking was applied to the field of learning. From 2009 onwards, the number of publications increased sharply, from three in 2008 to 21 in 2009, to a peak of 36 works on this subject in 2012. In all likelihood, the number of published articles will continue to rise in the near future.

More than $70 \%$ of the research identified by Lai is devoted to the analysis of information processing and the effects of teaching and learning strategies. Studies including concept maps are in the latter group (Amadieu et al., 2009) along with other multimedia learning fields (D'Mello, Olney, WiIliams; Hays, 2012; Mu, 2010; Pradhan et al., 2011; Wiebe; Minogue; Gail-Jones; Cowley; Krebs, 2009).

In works where eye tracking is applied to concept maps, different kinds of previous studies are cited in order to contextualize and debate the design of the investigation carried out and the results obtained. Bibliographies about concept maps using other types of methodology are also cited, as mentioned previously in point 4 . It should also be pointed out that, due to the lack of previous research on maps studied using the eye tracking method, the references cited are studies where this methodology is applied to other kinds of tools or processes such as multimedia, graphs, reading, and resolving problems (table 4).

\section{Studies on concept maps applying eye tracking methodology}

An in-depth examination of available works on this subject has shown there are a total of 15 investigations into concept maps published between 2007 and 2014 in which eye tracking methodology was applied. See table 4 . Searches were carried out in Google Scholar, Web of Science, Scopus, and $E R I C$ in order to find publications in which eye tracking was used to study all kinds of concept maps. As stated previously in the section on methodology, we have used the most common terms both for the concept of "concept map", with the keywords "concept map", "knowledge map", "graphic organizer", and "node-link maps", as well as the concept "eye tracking", with the keywords "eye tracking" and "eye movement" in their various forms. We later used bibliographical references from articles to find some non-indexed documents such as statements in congresses, PhD dissertations, postgraduate theses, or technical reports.

The amount of literature regarding the application of eye tracking methodology in concept maps is somewhat scarce and the sources are dispersed and difficult to locate, despite the fact that eye tracking methodology lends itself naturally to the study of concept maps

The end result was a total of 15 publications comprising two PhD dissertations, five congress presentations, one technical document, and seven articles. The first reference was published in 2007 and the most recent in 2014 . 80\% of the documents are indexed in Google Scholar, 66\% in Scopus, and $40 \%$ in Web of Science.

The works published are scattered and do not tend to cite each other. If we do not include the articles which are selfcited, there are only four remaining works which are cited in other documents within this group:

- Amadieu et al., 2009 are cited by Bisra, 2010; Dogusoy, 2012; P. L. Liu, 2014; Van-Amelsvoort; Van-der-Meij; Anjewierden; Van-der-Meij, 2013.

- J. C. Nesbit; Larios; Adesope, 2007 are cited by Bisra, 2010; Dogusoy, 2012; P. L. Liu, 2014; Van-Amelsvoort et al., 2013.

- Bisra, 2010 is cited by P. L. Liu, 2014.

- Van-Amelsvoort et al., 2013 are cited by P. L. Liu, 2014.

There are two factors that highlight the lack of research in this area: only $40 \%$ of the works published are indexed in the Web of Science database and only one of them (Amadieu et al., 2009) has received a significant number of citations: 40 in Web of Science, 46 in Scopus, and 106 in Google Scholar.

Most of the works use the terms "concept map" or "graphic organizer" and cite Novak in a generalized way. It is surprising that no publications were located dealing with the line

Table 4. Different lines of work published previously on eye tracking cited in those studies where this methodology is applied to concept maps

\begin{tabular}{|l|l|}
\hline \multicolumn{1}{|c|}{ Eye tracking applied to } & \multicolumn{1}{c|}{ Main authors } \\
\hline Multimedia and graphs & $\begin{array}{l}\text { Hyönä, 2010; H. C. Liu; Lai; Chuang, 2011; Mayer, 2010; Ozcelik; Arslan-Ari; Cagiltay, 2010; Ozcelik; Ka- } \\
\text { rakus; Kursun; Cagiltay, 2009; She; Chen, 2009; Van-Gog; Scheiter, 2010 }\end{array}$ \\
\hline Reading comprehension & Findlay; Gilchrist, 2003; Rayner et al., 2006; Rayner, 1998; Frenck-Mestre; Pynte, 1997; Frenck-Mestre, 2005 \\
\hline Problem solving & Crowe; Averbeck; Chafee; Anderson; Georgopoulos, 2000; Epelboim; Suppes, 2001; Grant; Spivey, 2003 \\
\hline
\end{tabular}


Table 5. Published works on concept maps applied to eye tracking

\begin{tabular}{|c|c|c|c|c|c|}
\hline Year & Title of the article & Author/s & $\begin{array}{l}\text { Term used in } \\
\text { the article }\end{array}$ & $\begin{array}{l}\text { Citations received: } \\
\text { Google Scholar / } \\
\text { Scopus / WoS }\end{array}$ & $\begin{array}{l}\text { Citations received: } \\
\text { from among the } \\
15 \text { publications } \\
\text { selected }\end{array}$ \\
\hline 2014 & $\begin{array}{l}\text { Using eye tracking to understand learners' } \\
\text { reading process through the concept-map- } \\
\text { ping learning strategy }\end{array}$ & P. L. Liu, 2014 & $\begin{array}{l}\text { Concept map- } \\
\text { ping }\end{array}$ & $0 / 0 / 0$ & 0 \\
\hline 2014 & $\begin{array}{l}\text { Cognitive analysis of 'Experts and Novices' } \\
\text { concept mapping processes: An eye track- } \\
\text { ing study }\end{array}$ & $\begin{array}{l}\text { Dogusoy-Taylan; } \\
\text { Cagiltay, } 2014\end{array}$ & Concept map & $2 / 0 / 0$ & 0 \\
\hline 2014 & $\begin{array}{l}\text { An eye movement analysis of highlighting } \\
\text { and graphic organizer study aids for learn- } \\
\text { ing from expository text }\end{array}$ & Ponce; Mayer, 2014a & $\begin{array}{l}\text { Graphic orga- } \\
\text { nizer }\end{array}$ & $0 / 0 / 0$ & 0 \\
\hline 2014 & $\begin{array}{l}\text { Qualitatively different cognitive processing } \\
\text { during online reading primed by different } \\
\text { study activities }\end{array}$ & Ponce; Mayer, 2014b & $\begin{array}{l}\text { Graphic orga- } \\
\text { nizer }\end{array}$ & $4 /-/ 2$ & 0 \\
\hline 2013 & $\begin{array}{l}\text { How users read concept maps: An eye- } \\
\text { tracking study }\end{array}$ & Rovira, 2013 & Concept map & $0 / 0 /-$ & 0 \\
\hline 2013 & $\begin{array}{l}\text { The importance of design in learning from } \\
\text { node-link diagrams }\end{array}$ & $\begin{array}{l}\text { Van-Amelsvoort et } \\
\text { al., } 2013\end{array}$ & $\begin{array}{l}\text { Node-link dia- } \\
\text { grams }\end{array}$ & $3 / 0 / 0$ & 1 \\
\hline 2012 & $\begin{array}{l}\text { Learning from concept maps: Validating the } \\
\text { use of eye-movement data }\end{array}$ & Bisra; Nesbit, 2012b & Concept map & $-/-/-$ & 0 \\
\hline 2012 & $\begin{array}{l}\text { How learners visually navigate concept } \\
\text { maps: An analysis of eye movement single } \\
\text { transitions }\end{array}$ & Bisra; Nesbit, 2012a & Concept map & $-/-/-$ & 0 \\
\hline 2012 & $\begin{array}{l}\text { Cognitive analysis of 'experts and novices' } \\
\text { concept mapping processes }\end{array}$ & Dogusoy-Taylan, 2012 & Concept map & $2 /-/-$ & 0 \\
\hline 2011 & $\begin{array}{l}\text { Analyzing students' eye movements of their } \\
\text { EFL reading with concept mapping strategy }\end{array}$ & $\begin{array}{l}\text { P. L. Liu; Wen; Lai; } \\
\text { Chen, } 2011\end{array}$ & $\begin{array}{l}\text { Concept map- } \\
\text { ping }\end{array}$ & $-/ 0 /-$ & 0 \\
\hline 2010 & $\begin{array}{l}\text { Experts' \& novices' concept map formation } \\
\text { process: An eye-tracking study }\end{array}$ & Dogusoy-Taylan, 2010 & Concept map & $0 / 0 /-$ & 0 \\
\hline 2010 & $\begin{array}{l}\text { How learners visually navigate concept } \\
\text { maps: an analysis of eye movements }\end{array}$ & Bisra, 2010 & Concept map & $1 /-/-$ & 1 \\
\hline 2009 & $\begin{array}{l}\text { Effects of prior knowledge and concept- } \\
\text { map structure on disorientation, cognitive } \\
\text { load, and learning }\end{array}$ & Amadieu et al., 2009 & Concept-map & $106 / 46 / 40$ & 4 \\
\hline 2008 & $\begin{array}{l}\text { Effects of knowledge interdependence with } \\
\text { the partner on visual and action transactiv- } \\
\text { ity in collaborative concept mapping }\end{array}$ & $\begin{array}{l}\text { Molinari; Sangin; } \\
\text { Nüssli; Dillenbourg, } \\
2008\end{array}$ & $\begin{array}{l}\text { Concept map- } \\
\text { ping }\end{array}$ & $10 / 0 /-$ & 0 \\
\hline 2007 & $\begin{array}{l}\text { How students read concept maps: A study } \\
\text { of eye movements }\end{array}$ & Nesbit et al., 2007 & Concept map & $8 / 1 /-$ & 4 \\
\hline
\end{tabular}

of work involving knowledge maps (McCagg; Dansereau, 1991), especially when considering that scientific production in this field is focused on learning with the aid of map reading.

There are three more items of research analyzing concept maps by means of eye tracking which have not been included in this selection, because they correspond to lines of research with theoretical grounding in the field of information visualization and are used for different reasons when compared to those maps utilized in teaching and learning (Burch; Heinrich; Konevtsova; Höferlin; Weiskopf, 2011; Jianu; Rusu; Hu; Taggart, 2014; Ware; Gilman; Bobrow, 2008).

The works of Dogusoy (2010, 2012, 2014) and Amadieu (2009) analyze the difference between experts and novices. Dogusoy studies the cognitive process of experts and novices when faced with creating concept maps and comes to the conclusion that, although they apply some similar strategies, both groups of users follow different patterns in the processing and development of concept maps. Amadieu explores this learning process by consulting concept maps and considering two variable factors: the degree of prior knowledge of the students and the structure of the concept maps (hierarchic or network). The results showed that those learners with very little previous knowledge were able to assimilate the same level of factual knowledge using hierarchic maps or networks, but the hierarchic maps achieved better results in conceptual knowledge. Those learners with greater prior knowledge, however, achieved a higher mark in factual learning using network maps, but overall obtained the same results in conceptual concepts using both kinds of maps.

Molinari (2008) analyzed the creation of concept maps in a collaborative way. Nesbit (2007), Rovira (2013), Bisra (2010), 
and Van-Amelsvoor (2013) base their studies on the way in which learners consult concept maps. The works of Nesbit and Rovira reach compatible conclusions despite employing maps containing different structures: hierarchic structures in the case of Rovira, and network structures in the article by Nesbit. In both cases, they conclude that those areas which best grasp the learners' attention are root concepts (upper concept in hierarchic maps and central concept in the cases of network maps), in which their attention moved towards the top left area of the screen. Bisra also obtained the following results regarding the use of maps: processing nodes requires more time than link phrases; the learner is guided by the lines which join concepts and the users tend not to follow the directions indicated by arrows associated to the link phrases. The findings in Van-Amelsvoort's studies show that the characteristics of the concepts located at the top condition the behavior of how the map is used. Van-Amelsvoort did, however, use a graphic organizer containing nodes and link phrases in a matrix form in his research, which cannot really be compared to maps used in other studies.

\section{Concept maps are graphs that we read, and eye tracking has been used suc- cessfully both in graph reading and rea- ding comprehension}

The works by Ponce (2014a, 2014b) and Liu (2011, 2014) compare the differences in behavior of learners faced with the task of reading a text alongside a map. It could be argued that, as a rule, it is likewise unadvisable to draw general conclusions from these publications when applying them to concept maps, as the learners used a combination of text and map reading, which is far more complex than simple map visualization.

In some cases eye tracking was applied in a somewhat inefficient manner, setting excessively ambitious targets where this method is unlikely to yield realistic results. The maps used are large and contain very complicated structures. The users carried out difficult tasks involving too many unmanageable variables. It is more advisable to follow the model of concept maps devised by Rayner (1998; 2006), which are applied to the study of reading, where just one specific and exhaustive control of intervening variables is examined.

\section{Conclusions}

In this article we have analyzed the theoretical groundwork in concept maps while identifying the main lines of research, the most relevant theories, and the most common subject matter. Our examination is concerned with those basic theories where eye tracking methodology is applied to the study of concept maps. Fifteen published works were located, comprising two PhD dissertations, five congress presentations, one technical document, and seven articles. The conclusions drawn from analyzing these works are that they are dispersed and difficult to visualize. The previous references of these publications are investigations where eye tracking methodology was used for multimedia studies, graphs, reading comprehension, and problem-solving. It should also be pointed out that in some cases this methodology has not been applied efficiently and there is a lack of control in managing intervening variables: the maps are too large, the tasks are too long, and the targets set are overambitious.

Investigation into eye tracking methodology has generally been employed in studies involving learning or teaching (Lai et al., 2013). Since the nineties, however, a wide range of material has been published on concept maps which tend to focus on psychology in learning (Nesbit; Adesope, 2006, 2013). In contrast, there appear to be few works in which eye tracking has been applied in research about concept maps, despite its proven effectiveness (Rovira 2010). This methodology allows us to obtain evidence as to the cognitive process which users employ while interacting with this kind of tool, especially in terms of attention and perception. It is a surprising situation, as concept maps are basically graphs containing a significant amount of text, and are therefore graphs which we read. Eye tracking has been used successfully in studies on graph reading (Mayer, 2010) as well as reading comprehension, where it has a substantial track record over the years (Rayner et al., 2006; Rayner, 1998). Consequently, we can confidently predict that in the near future there will be many more works on this subject (Adesope; Nesbit, 2013). In fact, $40 \%$ of the entire research in this field has taken place over the last two years.

\section{Bibliography}

Adesope, Olusola O.; Nesbit, John C. (2009). "A systematic review of research on collaborative learning using concept mapping". In: Lupion-Torres, Patricia; De-Cássia-Veiga-Marriott, Rita. Handbook of research on collaborative learning using concept mapping. Hershey, PA: IGI Global, pp. 238255. ISBN: 9781599049922

http://dx.doi.org/10.4018/978-1-59904-992-2

Adesope, Olusola O.; Nesbit, John C. (2013). "Animated and static concept maps enhance learning from spoken narration". Learning and instruction, v. 27, pp. 1-10. http://dx.doi.org/10.1016/j.learninstruc.2013.02.002

Åhlberg, Mauri (2004). "Varieties of concept mapping". In: Procs. of the First intl. conf on concept mapping, pp. 1-4. http://cmc.ihmc.us/papers/cmc2004-206.pdf

Amadieu, Franck; Van Gog, Tamara; Paas, Fred; Tricot, André; Mariné, Claudette (2009). "Effects of prior knowledge and concept-map structure on disorientation, cognitive load, and learning". Learning and instruction, v. 19, n. 5, pp. 376-386. http://dx.doi.org/10.1016/j.learninstruc.2009.02.005

Anderson-Inman, Lynne; Horney, Mark (1996). “Computerbased concept mapping: enhancing literacy with tools for visual thinking". Journal of adolescent \& adult literacy, v. 40, n. 4, pp. 302-306.

Ausubel, David-Paul (1960). "The use of advance organizers in the learning and retention of meaningful verbal material". Journal of educational psychology, v. 51, n. 5, pp. 267-272. http://dx.doi.org/10.1037/h0046669 
Ausubel, David-Paul (1963). The psychology of meaningful verbal learning, Oxford: England: Grune \& Stratton. ISBN: 9780808900252

Ausubel, David-Paul (1978). "In defense of advance organizers: A reply to the critics". Review of educational research, v. 48 , n. 2, pp. 251-257.

http://www.jstor.org/stable/1170083?seq=1\#page_scan_ tab_contents

Ausubel, David-Paul (2012). The acquisition and retention of knowledge: a cognitive view. Springer Netherlands. ISBN: 9789401594547

Ausubel, David-Paul; Novak, Joseph D.; Hanesian, Helen (1968). Educational psychology: A cognitive view. New York: Holt, Rinehart and Winston. ISBN: 9780030696404 https://books.google.es/books?id=HINpAAAAMAAJ

Ball, Linden J.; Lucas, Erica J.; Miles, Jeremy N. V.; Gale, Alastair G. (2003). "Inspection times and the selection task: what do eye-movements reveal about relevance". The quarterly journal of experimental psychology. A human experimental psychology, v. 56, n. 6, pp. 1053-1077.

http://dx.doi.org/10.1080/02724980244000729

Bisra, Kiran (2010). "How learners visually navigate concept maps: an analysis of eye movements". Thesis. Faculty of Education. Simon Fraser University.

http://summit.sfu.ca/system/files/iritems1/12811/ etd6060_KBisra.pdf

Bisra, Kiran; Nesbit, John C. (2012a). "From the how learners visually navigate concept maps: An analysis of eye movement single transitions". In: American Educational Research Association annual conf.

http://www.aera.net/repository

Bisra, Kiran; Nesbit, John C. (2012b). "Learning from concept maps: validating the use of eye-movement data". In: American Educational Research Association annual conf. http://www.aera.net/repository

Burch, Michael; Heinrich, Julian; Konevtsova, Natalia; Höferlin, Markus; Weiskopf, Daniel (2011). "Evaluation of traditional, orthogonal, and radial tree diagrams by an eye tracking study". IEEE Transactions on visualization and computer graphics, v. 17, n. 12, pp. 2440-2448.

http://dx.doi.org/10.1109/TVCG.2011.193

Buzan, Tony; Buzan, Barry (1995). The mind map book: Radiant thinking - Major evolution in human thought. London: BBC Worldwide Publishing. ISBN: 9780563537328

Cañas, Alberto J.; Coffey, John W.; Carnot, Mary-Jo; Feltovich, Paul; Hoffman, Robert R.; Feltovich, Joan; Novak, Joseph D. (2003). "A summary of literature pertaining to the use of concept mapping techniques and technologies for education and performance support", pp. 1-108.

http://www.ihmc.us/users/acanas/publications/ conceptmaplitreview/ihmc\%20literature\%20review\%20 on\%20concept\%20mapping.pdf

Chang, Kuo-En; Sung, Yao-Ting; Chen, S. F. (2001). "Learning through computer-based concept mapping with scaffolding aid". Journal of computer assisted learning, v. 17, n. 1, pp. 21-33. http://dx.doi.org/10.1111/j.1365-2729.2001.00156.x

Collins, Allan M.; Quillian, M. Ross (1969). "Retrieval time from semantic memory". Journal of verbal learning and verbal behavior, v. 8, n. 2, pp. 240-247.

http://dx.doi.org/10.1016/S0022-5371(69)80069-1

Cristea, Alexandra I.; Okamoto, Toshio (2001). “Objectoriented collaborative course authoring environment supported by concept mapping in MyEnglishTeacher". Journal of educational technology \& society, v. 4, n. 2, pp. 104-115. http://dx.doi.org/10.2307/jeductechsoci.4.2.104

Crowe, David A.; Averbeck, Bruno B.; Chafee, Matthew V.; Anderson, John H.; Georgopoulos, Apostolos P. (2000). "Mental maze solving". Journal of cognitive neuroscience, $\mathrm{v}$. 12, n. 5, pp. 813-827.

http://dx.doi.org/10.1162/089892900562426

D’Mello, Sidney; Olney, Andrew; Williams, Claire; Hays, Patrick (2012). "Gaze tutor: A gaze-reactive intelligent tutoring system". International journal of human-computer studies, v. 70, n. 5 , pp. 377-398.

http://dx.doi.org/10.1016/j.ijhcs.2012.01.004

Daley, Barbara J.; Shaw, Christine R.; Balistrieri, Toni; Glasenapp, Kate; Piacentine, Linda (1999). "Concept maps: a strategy to teach and evaluate critical thinking". The journal of nursing education, v. 38, n. 1, pp. 42-47.

http://jcnrsttt.wikispaces.com/file/view/Concept+Maps.pdf

Dansereau, Donald F. (2005). "Node-link mapping principles for visualizing knowledge and information". LNCS, v. 3426, pp. 61-81.

http://link.springer.com/chapter/10.1007\%2F11510154_4

Dansereau, Donald F.; Moreland, Jeremy L.; Chmielewski, Todd L. (1997). "Recall of descriptive information: the roles of presentation format, annotation strategy, and individual differences". Contemporary educational psychology, v. 22, n. 4, pp. 521-33.

http://dx.doi.org/10.1006/ceps.1997.0950

Davies, Martin (2011). “Concept mapping, mind mapping and argument mapping: What are the differences and do they matter?". Higher education, v. 62, n. 3, pp. 279-301. http://dx.doi.org/10.1007/s10734-010-9387-6

DiCecco, Vonnie M.; Gleason, Mary M. (2008). “Using graphic organizers to attain relational knowledge from expository text". Journal of learning disabilities, v. 35, n. 4, pp. 306-320.

http://dx.doi.org/10.1177/00222194020350040201

Dogusoy-Taylan, Berrin (2010). “Experts' \& novices' concept map formation process: an eye-tracking study". In: Fifth Doctoral Consortium at the European conference on technology enhanced learning, pp. 25-30.

http://ceur-ws.org/Vol-709/dc-ectel2010.pdf\#page=30

Dogusoy-Taylan, Berrin (2012). "Cognitive analysis of experts' and novices'. concept mapping processes". Thesis of Computer Education and Instructional Technology Department, Middle East Technical University. https://etd.lib.metu.edu.tr/upload/12614483/index.pdf

Dogusoy-Taylan, Berrin; Cagiltay, Kursat (2014). “Cognitive 
analysis of experts' and novices' concept mapping processes: An eye tracking study". Computers in human behavior, v. 36, pp. 82-93.

http://dx.doi.org/10.1016/j.chb.2014.03.036

Duchowski, Andrew (2003). Eye tracking methodology: Theory and practice. London: Springer. ISBN: 978184628 6094

Edmondson, Katherine M. (2000). "Assessing science understanding through concept maps". In: Assessing science understanding: A human constructivist view, pp. 15-40. San Diego: Academic Press. ISBN: 9780124983656

Epelboim, Julie; Suppes, Patrick (2001). “A model of eye movements and visual working memory during problem solving in geometry". Vision research, v. 41, n. 12, pp. 1561-1574. http://dx.doi.org/10.1016/S0042-6989(00)00256-X

Eppler, Martin J. (2006). "A comparison between concept maps, mind maps, conceptual diagrams, and visual metaphors as complementary tools for knowledge construction and sharing". Information visualization, v. 5, n. 3, pp. 202-210. http://dx.doi.org/10.1057/palgrave.ivs.9500131

Esiobu, Gladys O; Soyibo, Kola (1995). “Effects of concept and vee mappings under three learning modes on students' cognitive achievement in ecology and genetics". Journal of research in science teaching, v. 32, n. 9, pp. 971-995. http://dx.doi.org/10.1002/tea.3660320908

Estes, Thomas H.; Mills, Daniel C.; Barron, Richard F. (1969). "Three methods of introducing students to a reading-learning task in two content subjects". In: Herber, Harold L.; Sanders, Peter L. (eds). Research in reading in the content areas: First year report, pp. 44-47.

http://files.eric.ed.gov/fulltext/ED037305.pdf\#page $=45$

Findlay, John M.; Gilchrist, lain D. (2003). Active vision: The psychology of looking and seeing, Oxford: Oxford University Press. ISBN: 9780198524793

Frenck-Mestre, Cheryl; Pynte, Joel (1997). "Syntactic ambiguity resolution while reading in second and native languages". Quarterly journal of experimental psychology, v. 50A, n. 1 , pp. 119-148.

http://dx.doi.org/10.1080/027249897392251

Ghoniem, Mohammad; Fekete, Jean-Daniel; Castagliola, Philippe (2004). "A comparison of the readability of graphs using node-link and matrix-based representations". IEEE Symposium on information visualization, pp. 17-24.

http://dx.doi.org/10.1109/INFVIS.2004.1

Ghoniem, Mohammad; Fekete, Jean-Daniel; Castagliola, Philippe (2005). "On the readability of graphs using nodelink and matrix-based representations: a controlled experiment and statistical analysis". Information visualization, v. 4, n. 2, pp. 114-135.

http://dx.doi.org/10.1057/palgrave.ivs.9500092

Grant, Elizabeth R.; Spivey, Michael J. (2003). "Eye movements and problem solving". Psychological science - Cambridge, v. 14, n. 5, pp. 462-466.

http://miwalab.cog.human.nagoya-u.ac.jp/database/ paper/2011-02-17.pdf
Hall, Richard H.; O’Donnell, Angela (1996). "Cognitive and affective outcomes of learning from knowledge maps". Contemporary educational psychology, v. 21, n. 1, pp. 94-101. http://dx.doi.org/10.1006/ceps.1996.0008

Haspelmath, Martin (2000). "The geometry of grammatical meaning: Semantic maps and cross-linguistic comparison". The new psychology of language, v. II, n. 1976, pp. 1-30. http://wwwstaff.eva.mpg.de/ haspelmt/SemMaps.pdf

Haugwitz, Marion; Nesbit, John C.; Sandmann, Angela (2010). "Cognitive ability and the instructional efficacy of collaborative concept mapping". Learning and individual differences, v. 20, n. 5, pp. 536-543.

http://dx.doi.org/10.1016/j.lindif.2010.04.004

Hay, David B. (2007). "Using concept maps to measure deep, surface and non-learning outcomes". Studies in higher education, v. 32, n. 1, pp. 39-57.

http://dx.doi.org/10.1080/03075070601099432

Hegarty, Mary; Just, Marcel-Adam (1993). “Constructing mental models of machines from text and diagrams". Journal of memory and language, v. 32, n. 6, pp. 717-742. http://dx.doi.org/10.1006/jmla.1993.1036

Henry, Nathalie; Fekete, Jean-Daniel; McGuffin, Michael J. (2007). "NodeTrix: A hybrid visualization of social networks". IEEE Transactions on visualization and computer graphics, v. 13, n. 6, pp. 1302-1309.

http://dx.doi.org/10.1109/TVCG.2007.70582

Holmqvist, Kenneth; Nyström, Marcus; Andersson, Richard; Dewhurst, Richard; Jarodzka, Halszka; Van-deWeijer, Joost (2011). Eye tracking: A comprehensive guide to methods and measures. Oxford: Oxford University Press. ISBN: 9780199697083

Holten, Danny; Van-Wijk, Jarke J. (2009). "Force-directed edge bundling for graph visualization". Computer graphics forum, v. 28, n. 3, pp. 983-990.

http://dx.doi.org/10.1111/j.1467-8659.2009.01450.x

Horton, Phillip B.; McConney, Andrew A.; Gallo, Michael; Woods, Amanda L.; Senn, Gary J.; Hamelin, Denis (1993). "An investigation of the effectiveness of concept mapping as an instructional tool". Science education, v. 77, n. 1, pp. 95-111.

http://dx.doi.org/10.1002/sce.3730770107

Hyönä, Jukka (2010). "The use of eye movements in the study of multimedia learning". Learning and instruction, v. 20, n. 2, pp. 172-176.

http://dx.doi.org/10.1016/j.learninstruc.2009.02.013

Jiang, Xiangying; Grabe, William (2007). "Graphic organizers in reading instruction: Research findings and issues". Reading in a foreign language, v. 19, n. 1, pp. 34-55. http://nflrc.hawaii.edu/rfl/April2007/jiang/jiang.pdf

Jianu, Radu; Rusu, Adrian; Hu, Yifan; Taggart, Douglas (2014). "How to display group information on node-link diagrams: An evaluation". IEEE Transactions on visualization and computer graphics, v. 20, n. 11, pp. 1530-1541. http://dx.doi.org/10.1109/TVCG.2014.2315995

Just, Marcel A.; Carpenter, Patricia A. (1980). "A theory of 
reading: From eye fixations to comprehension". Psychological review, v. 87, n. 4, pp. 329-354.

http://dx.doi.org/10.1037/0033-295X.87.4.329

Karpicke, Jeffrey D.; Blunt, Janell R. (2011). "Retrieval practice produces more learning than elaborative studying with concept mapping". Science (New York), v. 331, n. 6018, pp. 772-775.

http://dx.doi.org/10.1126/science.1204035

Kinchin, Ian M.; Hay, David B.; Adams, Alan (2000). "How a qualitative approach to concept map analysis can be used to aid learning by illustrating patterns of conceptual development". Educational research, v. 42, n. 1, pp. 43-57.

http://dx.doi.org/10.1080/001318800363908

Kulhavy, Raymond W.; Lee, J. Brandon; Caterino, Linda C. (1985). "Conjoint retention of maps and related discourse". Contemporary educational psychology, v. 10, n. 1, pp. 28-37. http://www.sciencedirect.com/science/article/ pii/0361476X85900037

http://dx.doi.org/10.1016/0361-476X(85)90003-7

Lai, Meng-Lung; Tsai, Meng-Jung; Yang, Fang-Ying; Hsu, Chung-Yuan; Liu, Tzu-Chien; Lee, Silvia-Wen-Yu; Lee, MinHsien; Chiou, Guo-Li; Liang, Jyh-Chong; Tsai, Chin-Chung (2013). "A review of using eye-tracking technology in exploring learning from 2000 to 2012". Educational research review, v. 10, n. 88, pp. 90-115.

http://dx.doi.org/10.1016/j.edurev.2013.10.001

Lambiotte, Judith G.; Dansereau, Donald F. (1992). "Effects of knowledge maps and prior knowledge on recall of science lecture content". The journal of experimental education, v. 60, n. 3, pp. 189-201.

http://dx.doi.org/10.1080/00220973.1992.9943875

Lambiotte, Judith G.; Dansereau, Donald F.; Cross, David R.; Reynolds, Sharon B. (1989). "Multirelational semantic maps". Educational psychology review, v. 1, n. 4, pp. 331367.

http://dx.doi.org/10.1007/BF01320098

Leontyev, Aleksei-Nikolaevich (1972). Activity and consciousness, Moscow: Progress Publishers.

https://www.marxists.org/archive/leontev/works/1977/ leon1977.htm

Lim, Kyu-Yon; Lee, Hyeon-Woo; Grabowski, Barbara (2009). "Does concept-mapping strategy work for everyone? The levels of generativity and learners' self-regulated learning skills". British journal of educational technology, v. 40, n. 4, pp. 606-618.

http://dx.doi.org/10.1111/j.1467-8535.2008.00872.x

Liu, Han-Chin; Lai, Meng-Lung; Chuang, Hsueh-Hua (2011). "Using eye-tracking technology to investigate the redundant effect of multimedia web pages on viewers' cognitive processes". Computers in human behavior, v. 27, n. 6, pp. 2410-2417.

http://dx.doi.org/10.1016/j.chb.2011.06.012

Liu, Pei-Lin (2014). “Using eye tracking to understand learners' reading process through the concept-mapping learning strategy". Computers and education, v. 78, pp. 237-249. http://dx.doi.org/10.1016/j.compedu.2014.05.011
Liu, Pei-Lin; Wen, Pang-Cheng; Lai, Meng-Lung; Chiu-Jung, Chen (2011). "Analyzing students' eye movements of their EFL reading with concept mapping strategy". Procs of the $19^{\text {th }}$ Int conf on computers in education, ICCE 2011, pp. 31-38. http://www.nectec.or.th/icce2011/program/proceedings

Marcos, Mari-Carmen; González-Caro, Cristina (2010). "Comportamiento de los usuarios en la página de resultados de los buscadores. Un estudio basado en eye tracking". El profesional de la información, v. 19, n. 4, pp. 348-358. http://dx.doi.org/10.3145/epi.2010.jul.03

Markham, Kimberly M.; Mintzes, Joel J.; Jones, M. Gail (1994). "The concept map as a research and evaluation tool: Further evidence of validity". Journal of research in science teaching, v. 31, n. 1, pp. 91-101.

http://dx.doi.org/10.1002/tea.3660310109

Mayer, Richard E. (1979). "Can advance organizers influence meaningful learning?". Review of educational research, v. 49, n. 2, pp. 371-383.

http://dx.doi.org/10.3102/00346543049002371

Mayer, Richard E. (2010). "Unique contributions of eyetracking research to the study of learning with graphics". Learning and instruction, v. 20, n. 2, pp. 167-171. http://dx.doi.org/10.1016/j.learninstruc.2009.02.012

McCagg, Edward C.; Dansereau, Donald F. (1991). "A convergent paradigm for examining knowledge mapping as a learning strategy". Journal of educational research, v. 84, n. 6, pp. 317-324.

http://dx.doi.org/10.1080/00220671.1991.9941812

Merkley, Donna M.; Jefferies, Debra (2000). “Guidelines for implementing a graphic organizer". The reading teacher, $\mathrm{v}$. 54, n. 4 , pp. 350-357.

http://connection.ebscohost.com/c/articles/3893085/ guidelines-implementing-graphic-organizer

Milam, John H.; Santo, Susan A.; Heaton, Lisa A. (2000). "Concept maps for web-based applications". ERIC Technical report.

http://citeseerx.ist.psu.edu/viewdoc/download?doi=10.1.1. 123.2302\&rep $=$ rep1\&type $=p d f$

Molinari, Gaëlle; Sangin, Mirweis; Nüssli, Marc-Antoine; Dillenbourg, Pierre (2008). "Effects of knowledge interdependence with the partner on visual and action transactivity in collaborative concept mapping". In: $8^{\text {th }}$ Intl conf of the learning sciences 2008 (ICLS 2008), v. 2, pp. 91-98.

http://dl.acm.org/citation.cfm? $\mathrm{id}=1599883 \& d l=A C M \&$ coll= $D L \& C F I D=571307025 \&$ CFTOKEN $=83361407$

Moore, David W.; Readence, John F. (1984). "A quantitative and qualitative review of graphic organizer research". The journal of educational research, v. 78, n. 1, pp. 11-17. http://dx.doi.org/10.1080/00220671.1984.10885564

Mu, Xiangming (2010). "Towards effective video annotation: An approach to automatically link notes with video content". Computers \& education, v. 55, n. 4, pp. 1752-1763. http://dx.doi.org/10.1016/j.compedu.2010.07.021

Nesbit, John C.; Adesope, Olusola O. (2005). "Dynamic concept maps". In: EdMedia: World conf on educational media 
and technology, v. 2005, n. 1, pp. 4323-4329.

http://www.editlib.org/p/20758

Nesbit, John C.; Adesope, Olusola O. (2006). “Learning with concept and knowledge maps: A meta-analysis". Review of educational research, v. 76, n. 3, pp. 413-448.

http://dx.doi.org/10.3102/00346543076003413

Nesbit, John C; Adesope, Olusola O. (2011). "Learning from animated concept maps with concurrent audio narration". Journal of experimental education, v. 79, n. 2, pp. 209-230. http://dx.doi.org/10.1080/00220970903292918

Nesbit, John C.; Adesope, Olusola O. (2013). "Concept maps for learning". In: Gregory Schraw; Matthew T. McCrudden; Daniel Robinson (eds.). Learning through visual displays. Charlotte, NC: Information Age Publishing, pp. 303-328. ISBN: 9781623962333

Nesbit, John C.; Larios, Hector; Adesope, Olusola O. (2007). "How students read concept maps: a study of eye movements". In: C. Montgomerie; J. Seale (eds.). Proceedings of EdMedia: World conf on educational media and technology, pp. 3961-3970. Association for the Advancement of Computing in Education (AACE).

http://www.aace.org/conf/edmedia

http://www.editlib.org/p/25950

Novak, Joseph D. (1990a). “Concept mapping: A useful tool for science education". Journal of research in science teaching, v. 27, n. 10, pp. 937-949.

http://dx.doi.org/10.1002/tea.3660271003

Novak, Joseph D. (1990b). “Concept maps and vee diagrams: two metacognitive tools to facilitate meaningful learning". Instructional science, v. 19, n. 1, pp. 29-52.

http://dx.doi.org/10.1007/BF00377984

Novak, Joseph D. (1998). Learning, creating, and using knowledge: Concept maps(R) as facilitative tools in schools and corporations. Mahwah, NJ: Lawrence Erlbaum Associates. ISBN: 0805826262

Novak, Joseph D.; Cañas, Alberto J. (2006). "La teoría subyacente a los mapas conceptuales y cómo construirlos".

http://cmap.ihmc.us

http://www.cs.northwestern.edu/ paritosh/papers/sketchto-models/Novak-Canas-TheoryUnderlyingConceptMapsHQ. $p d f$

Novak, Joseph D.; Gowin, D. B. (1984). Learning how to learn. Cambridge: Cambridge University Press. ISBN: 0521319269

O’Donnell, Angela M.; Dansereau, Donald F.; Hall, Richard H. (2002). "Knowledge maps as scaffolds for cognitive processing". Educational psychology review.

http://dx.doi.org/10.1023/A:1013132527007

Okebukola, Peter-Akinsola; Olugbemiro, J. Jegede (1988). "Cognitive preference and learning mode as determinants of meaningful learning through concept mapping". Science education, v. 72, n. 4, pp. 489-500.

http://dx.doi.org/10.1002/sce.3730720408

Ozcelik, Erol; Arslan-Ari, Ismahan; Cagiltay, Kursat (2010). "Why does signaling enhance multimedia learning? Eviden- ce from eye movements". Computers in human behavior, v. 26 , n. 1 , pp. $110-117$.

http://dx.doi.org/10.1016/j.chb.2009.09.001

Ozcelik, Erol; Karakus, Turkan; Kursun, Engin; Cagiltay, Kursat (2009). "An eye-tracking study of how color coding affects multimedia learning". Computers \& education, v. 53, n. 2, pp. 445-453.

http://dx.doi.org/10.1016/j.compedu.2009.03.002

Paivio, Allan (1986). Mental representations. New York: Oxford University Press. ISBN: 0195362004

Paivio, Allan (1991). "Dual coding theory: retrospect and current status". Canadian journal of psychology, v. 45, n. 3, pp. 255-287.

http://dx.doi.org/10.1037/h0084295

Patterson, Michael E.; Dansereau, Donald F.; Wiegmann, Douglas A. (1993). "Receiving information during a cooperative episode: Effects of communication aids and verbal ability". Learning and individual differences, v. 5, n. 1, pp. 1-11. http://dx.doi.org/10.1016/1041-6080(93)90022-K

Pearsall, N. Renee; Skipper, Joel J.; Mintzes, Joel J. (1997). "Knowledge restructuring in the life sciences: A longitudinal study of conceptual change in biology". Science education, v. 81, n.2, pp. 193-215.

http://goo.gl/S8MijH

http://dx.doi.org/10.1002/(SICI)1098-237X(199704)81:2<193:AIDSCE5>3.0.CO;2-A

Ponce, Hector R.; Mayer, Richard E. (2014a). "An eye movement analysis of highlighting and graphic organizer study aids for learning from expository text". Computers in human behavior, v. 41, pp. 21-32.

http://dx.doi.org/10.1016/j.chb.2014.09.010

Ponce, Hector R.; Mayer, Richard E. (2014b). “Qualitatively different cognitive processing during online reading primed by different study activities". Computers in human behavior, v. 30, pp. 121-130.

http://dx.doi.org/10.1016/j.chb.2013.07.054

Pradhan, Anuj K.; Divekar, Gautam; Masserang, Kathleen; Romoser, Matthew R. E.; Zafian, Tracy; Blomberg, Richard D.; Thomas, F. Dennis; Reagan, Ian; Knodler, M; Pollatsek, Alexander; Fisher, Donald L. (2011). "The effects of focused attention training on the duration of novice drivers' glances inside the vehicle". Ergonomics, v. 54, n. 10, pp. 917-931. http://dx.doi.org/10.1080/00140139.2011.607245

Quillian, M. Ross (1967). "Word concepts: a theory and simulation of some basic semantic capabilities". Behavioral science, v. 12, n. 5, pp. 410-430.

http://dx.doi.org/10.1002/bs.3830120511

Rayner, Keith (1998). "Eye movements in reading and information processing: 20 years of research". Psychological bulletin, v. 124, n. 3, pp. 372-422.

http://dx.doi.org/10.1037/0033-2909.124.3.372

Rayner, Keith; Chace, Kathryn H.; Slattery, Timothy J.; Ashby, Jane (2006). "Eye movements as reflections of comprehension processes in reading". Scientific studies of reading, v. 10 , n. 3, pp. 241-255. 
http://dx.doi.org/10.1207/s1532799xssr1003_3

Robinson, Daniel H.; Katayama, Andrew D.; Dubois, Nelson F.; Devaney, Thomas (1998). "Interactive effects of graphic organizers and delayed review on concept application". The journal of experimental education, v. 67, n. 1.

http://dx.doi.org/10.1080/00220979809598342

Robinson, Daniel H.; Kiewra, Kenneth A. (1995). "Visual argument: Graphic organizers are superior to outlines in improving learning from text". Journal of educational psychology, v. 87, n. 3, pp. 455-467.

http://dx.doi.org/10.1037/0022-0663.87.3.455

Roth, Wolff-Michael; Roychoudhury, Anita (1992). "The social construction of scientific concepts or the concept map as conscription device and tool for social thinking in high school science". Science education, v. 76, n. 5, pp. 531-557. http://dx.doi.org/10.1002/sce.3730760507

Roth, Wolff-Michael; Roychoudhury, Anita (1993). "The concept map as a tool for the collaborative construction of knowledge: A microanalysis of high school physics students". Journal of research in science teaching, v. 30, n. 5, pp. 503-534.

http://dx.doi.org/10.1002/tea.3660300508

Rovira, Cristòfol (2005). "El editor de mapas conceptuales DigiDocMap y la norma Topic Maps". Hipertext.net, v. 3.

https://www.upf.edu/hipertextnet/numero-3/digidocmap. html

Rovira, Cristòfol (2013). "La consulta de mapes conceptuals: estudi mitjançant el seguiment de la mirada". BiD, v. 31.

http://www.scopus.com/inward/record.url?eid=2-s2.084898636325\&partnerID=tZOtx3y1

Rueda, Urko; Larranaga, Mikel; Arruarte, Ana; Elorriaga, Jon A. (2003). "Dynamic visualization of student models using concept maps". In: Artificial intelligence in education: Shaping the future of learning through intelligent technologies, v. 97, pp. 89-96. ISBN: 9781586033569

Ruiz-Primo, María-Araceli; Shavelson, Richard J. (1996). "Problems and issues in the use of concept maps in science assessment". Journal of research in science teaching, v. 33, n. 6, pp. 569-600.

http://goo.gl/M6VUz9

http://dx.doi.org/10.1002/(SICI)1098-2736(199608)33:6<569:AIDTEA1>3.0.CO;2-M

She, Hsiao-Ching; Chen, Yi-Zen (2009). "The impact of multimedia effect on science learning: Evidence from eye movements". Computers and education, v. 53, n. 4, pp. 1297-1307. http://dx.doi.org/10.1016/j.compedu.2009.06.012

Stewart, James; Van-Kirk, Judith; Rowell, Richard (1979). "Concept maps: A tool for use in biology teaching". American biology teacher, v. 41, n. 3, pp. 171-175.

http://dx.doi.org/10.2307/4446530

Stoyanova, Neli; Kommers, Piet (2002). “Concept mapping as a medium of shared cognition in computer-supported collaborative problem solving". Journal of interactive learning research, v. 13, n. 1, pp. 111-133. http://www.editlib.org/p/10783
Stull, Andrew T.; Mayer, Richard E. (2007). "Learning by doing versus learning by viewing: Three experimental comparisons of learner-generated versus author-provided graphic organizers". Journal of educational psychology, v. 99, n. 4, pp. 808-820.

http://dx.doi.org/10.1037/0022-0663.99.4.808

Sturm, Janet M.; Rankin-Erickson, Joan L. (2002). "Effects of hand-drawn and computer-generated concept mapping on the expository writing of middle school students with learning disabilities". Learning disabilities research \& practice, v. 17, n. 2, pp. 124-139.

http://dx.doi.org/10.1111/1540-5826.00039

Sweller, John (1988). "Cognitive load during problem solving: Effects on learning". Cognitive science, v. 12, n. 2, pp. 257-285.

http://dx.doi.org/10.1016/0364-0213(88)90023-7

Tramullas, Jesús; Sánchez-Casabón, Ana I.; Garrido-Picazo, Piedad (2009). "Gestión de información personal con software para mapas conceptuales". El profesional de la información, v. 18, n. 6, pp. 601-612.

http://dx.doi.org/10.3145/epi.2009.nov.03

Turns, Jennifer; Atman, Cynthia J.; Adams, Robin (2000). "Concept maps for engineering education: A cognitively motivated tool supporting varied assessment functions". IEEE Transactions on education, v. 43, n. 2, pp. 164-173.

http://dx.doi.org/10.1109/13.848069

Underwood, Geoffrey; Jebbett, Lorraine; Roberts, Katharine (2004). "Inspecting pictures for information to verify a sentence: Eye movements in general encoding and in focused search". The quarterly journal of experimental psychology. Section A: Human experimental psychology, v. 57, n. 1, pp. 165-182.

http://dx.doi.org/10.1080/02724980343000189

Van-Amelsvoort, Marije; Van-der-Meij, Jan; Anjewierden, Anjo; Van-der-Meij, Hans (2013). "The importance of design in learning from node-link diagrams". Instructional science, v. 41, n. 5, pp. 833-847.

http://dx.doi.org/10.1007/s11251-012-9258-x

Van-Boxtel, Carla; Van-der-Linden, Jos; Roelofs, Erik; Erkens, Gijsbert (2002). "Collaborative concept mapping: Provoking and supporting meaningful discourse". Theory into practice, v. 41, n. 1 , pp. 40-46.

http://dx.doi.org/10.1207/s15430421tip4101_7

Van-Der-Auwera, Johan (2008). "In defense of classical semantic maps". Theoretical linguistics, v. 34, n. 1, pp. 39-46. http://dx.doi.org/10.1515/THLI.2008.002

Van-Der-Auwera, Johan; Plungian, Vladimir A. (1998). “Modality's semantic map". Linguistic typology, v. 2, n. 1. http://dx.doi.org/10.1515/lity.1998.2.1.79

Van-Gog, Tamara; Scheiter, Katharina (2010). "Eye tracking as a tool to study and enhance multimedia learning". Learning and instruction, v. 20, n. 2, pp. 95-99.

http://dx.doi.org/10.1016/j.learninstruc.2009.02.009

Vekiri, loanna (2002). "What is the value of graphical displays in learning?". Educational psychology review, v. 14, n. 3, pp. 261-312. 
http://dx.doi.org/10.1023/A:1016064429161

Wallace, David S.; West, Sylvia-Wandell-Conner; Ware, Anne; Dansereau, Donald F. (1998). "The effect of knowledge maps that incorporate Gestalt principles on learning". The journal of experimental education, v. 67, n. 1, pp. 5-16. http://dx.doi.org/10.1080/00220979809598341

Wallace, Josephine D.; Mintzes, Joel J. (1990). “The concept map as a research tool: Exploring conceptual change in biology". Journal of research in science teaching, v. 27, n. 10, pp. 1033-1052.

http://dx.doi.org/10.1002/tea.3660271010

Waller, Robert (1981). "Understanding network diagrams". In: Annual Meeting of the American Educational Research Association.

Ware, Colin; Gilman, Anne T.; Bobrow, Robert J. (2008). "Visual thinking with an interactive diagram". In: Diagrammatic representation and inference. $5^{\text {th }}$ Int l conf., Diagrams 2008, pp. 118-126. http://dx.doi.org/10.1007/978-3-540-87730-1_13

Wiebe, Eric N.; Minogue, James; Jones, M. Gail; Cowley, Jennifer; Krebs, Denise (2009). "Haptic feedback and students' learning about levers: Unraveling the effect of simulated touch". Computers \& education, v. 53, n. 3, pp. 667-676. http://dx.doi.org/10.1016/j.compedu.2009.04.004

Wiegmann, Douglas; Dansereau, Donald F.; McCagg, Edward C.; Rewey, Kirsten L.; Pitre, Urvashi (1992). "Effects of knowledge map characteristics on information processing". Contemporary educational psychology, v. 17, n. 2, pp. 136-155. http://dx.doi.org/10.1016/0361-476X(92)90055-4

Willerman, Marvin; Mac-Harg, Richard A. (1991). "The concept map as an advance organizer". Journal of research in science teaching, v. 28, n. 8, pp. 705-711.

http://dx.doi.org/10.1002/tea.3660280807

Winn, William (1991). "Learning from maps and diagrams". Educational psychology review, v. 3, n. 3, pp. 211-247. http://dx.doi.org/10.1007/BF01320077

\section{INFORMES THINKEPI 2015 SOBRE DOCUMENTACIÓN Y COMUNICACIÓN}

Baiget, Tomàs (dir); Olea, Isabel (coord.) (2015). Informes ThinkEPI 2015. $17 \times 24 \mathrm{~cm}$. Barcelona: Editorial EPI, 213 pp. ISBN: 9788460682097

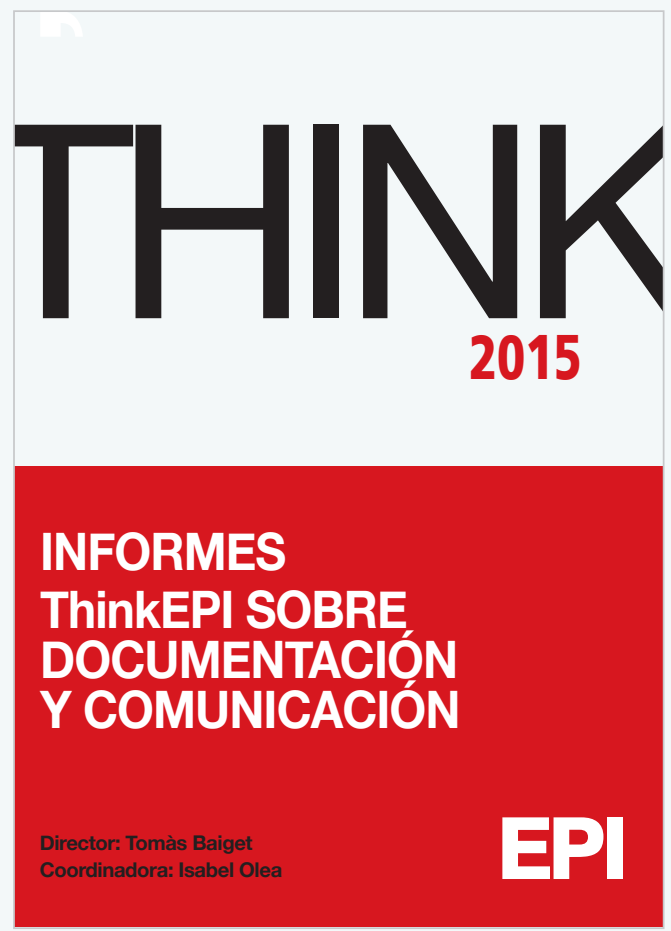

Pedidos: Isabel Olea

epi.iolea@gmail.com
Prólogo: La gran disrupción: la Web + los dispositivos móviles y lo que podemos hacer Lluís Codina

Bibliotecas virtuales en 2014, año de consolidación del modelo linked open data

Xavier Agenjo-Bullón

Tecnología móvil y bibliotecas en 2014: ampliando el concepto de movilidad

\section{Natalia Arroyo-Vázquez}

Encuesta internacional de automatización de bibliotecas Marshall Breeding

Moocs: estado actual, retos y oportunidades Josep Cobarsí-Morales

Los libros electrónicos: principales tendencias y prospectiva José-Antonio Cordón-García

Servicios de suscripción de libros electrónicos: modelos y tendencias

José-Antonio Cordón-García

Comunicación científica en 2014. En torno a la 'altmetría' Rodrigo Costas

Informe de la situación de los medios sociales en el sector de la información y la documentación en 2014 y prospectiva 2015 Nieves González-Fernández-Villavicencio

Medios de comunicación digitales en 2014: un balance alternativo

Pere Masip

Acceso abierto en 2014: se sigue avanzando

Remedios Melero y Ernest Abadal

Web semántica. Informe de situación 2014

Juan-Antonio Pastor-Sánchez y Tomás Saorín

Resumen de actividades de IFLA, Eblida, Liber y Fesabid en 2014

\section{Glòria Pérez-Salmerón}

Informe de situación 2015: profesión y formación universitaria Carlos-Miguel Tejada-Artigas 


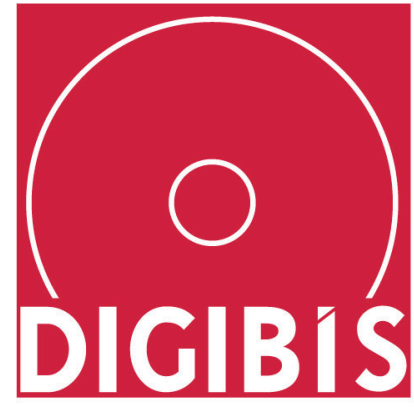

Digitalización enriquecida de fondo antiguo y patrimonial

Software de gestión para Bibliotecas, Archivos y Museos DIGIBIB ${ }^{\circ}$ DIGIARCH ${ }^{\circ}$ DIGIMUS ${ }^{\circ}$

Recolector OAI-PMH DIGIHUB' de metadatos de diversos proveedores

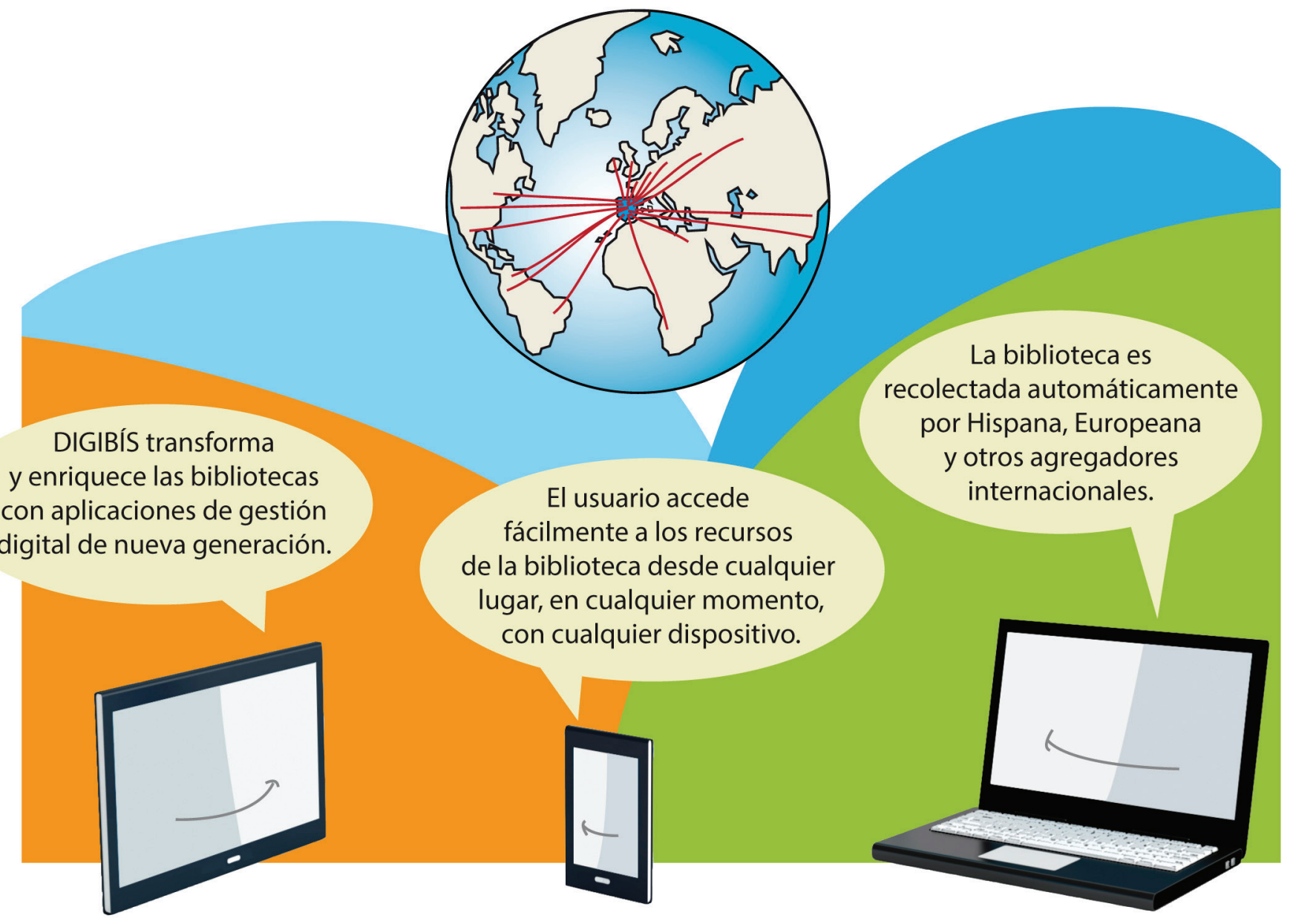

\section{¡Con estándares internacionales para un mundo enlazado y abierto!}

